Article

\title{
Global Hotspots of Conflict Risk between Food Security and Biodiversity Conservation
}

\author{
Amy Molotoks ${ }^{1, *} \mathbb{1}$, Matthias Kuhnert ${ }^{1}$, Terence P. Dawson ${ }^{2}$ and Pete Smith ${ }^{1}$ \\ 1 Institute of Biological and Environmental Sciences, University of Aberdeen, 23 St Machar Drive, Aberdeen, \\ AB24 3UU, UK; matthias.kuhnert@abdn.ac.uk (M.K.); pete.smith@abdn.ac.uk (P.S.) \\ 2 Department of Geography, King's College London, Strand, London WC2R 2LS, UK; terry.dawson@kcl.ac.uk \\ * Correspondence: r07am15@abdn.ac.uk; Tel.: +44-1224-273-810
}

Received: 26 May 2017; Accepted: 30 September 2017; Published: 4 October 2017

\begin{abstract}
The global challenges of food security and biodiversity are rarely addressed together, though recently there has been an increasing awareness that the two issues are closely related. The majority of land available for agriculture is already used for food production, but despite the productivity gains, one in nine people worldwide are classified as food insecure. There is an increasing risk that addressing food insecurity through methods such as agricultural expansion or intensification could lead to biodiversity loss through destruction of habitats important for conservation. This analysis uses various indicators of biodiversity at a global scale, including biodiversity hotspots, total species richness, and threatened and endemic species richness. Areas where high biodiversity coexists with high food insecurity or a high risk of agricultural expansion, were examined and found to mainly occur in the tropics, with Madagascar standing out in particular. The areas identified are especially at risk of biodiversity loss, and so are global priorities for further research and for policy development to address food insecurity and biodiversity loss together.
\end{abstract}

Keywords: biodiversity conservation; food security; land use

\section{Introduction}

Conserving biodiversity and increasing food security are two of the world's most pressing issues [1]. The two problems of food insecurity and biodiversity loss are both global in scope and must not be viewed independently [2]. In a world with limited resources, the methods used to address one necessarily involve choices affecting the other [2]. However, combining efficient agricultural land use with biodiversity conservation is a major challenge [3].

Food insecurity is largely attributed to poverty [3] and 75\% of people considered 'food insecure' live in rural areas, relying heavily on ecosystem services for primary services and goods $[4,5]$. Those who directly utilise biodiversity resources do not often have any alternatives, and hence there is a risk of the short term incentives of food and materials outweighing the long term stability of the ecosystem [4]. The importance of biodiversity to food security in areas of poverty cannot be overstated [6], as rural, poorer populations rely more heavily on biodiversity and often encroach on forests to extract natural products, increasing pressure on local fauna and flora [3]. Yet, conservation and poverty data have rarely been fully integrated [4] so there is a paucity of research specifically addressing the connections between food security and biodiversity [1].

Food security was defined at the 1996 World Food summit as 'existing when all people, at all times, have physical and economic access to sufficient safe and nutritious food that meets their dietary needs and food preferences for an active and healthy life' [7]. Despite huge productivity gains and the apparent success of the Green revolution [8], roughly one in nine people still lack access to food or are chronically malnourished [9]. Undernourishment affects approximately 795 million people 
worldwide [9] and the people suffering most from hunger or malnutrition are often those working in agricultural societies [10], which shows that the availability of food does not necessarily assure access [5,11].

Many food-insecure regions of the world also contain rich biodiversity, with biodiversity being defined as the variety of genes, species and ecosystems [1]. Often, agricultural expansion is one of the greatest threats to biodiversity [2], with habitat destruction and fragmentation from land use change being the predominant drivers of species extinctions [12]. Within the next few decades, developing countries could increase the total amount of cultivated land by an estimated 110 million hectares [13], which would pose significant threats to biodiversity [14]. One study shows that if projected land use changes by 2040 are realised, over 1000 threatened species worldwide would lose over $50 \%$ of their current ranges [15], therefore identifying areas of potential risk is of high importance.

This study has three aims: (a) to identify countries with the highest risk of conflict between biodiversity conservation and food security, (b) to show the biodiversity hotspots with the highest prevalence of food insecurity, and (c) to examine areas where high biodiversity overlaps with high risk of agricultural expansion. Each of these aims provide an insight to which areas are at high risk of biodiversity being lost as a result of food insecurity.

\section{Materials and Methods}

\subsection{Risk of Conflict Index}

We develop an index of potential conflict between food security and biodiversity which represents the risk of natural resource exploitation. This was constructed using the 2016 Global Food Security Index (GFSI) developed by the Economist Intelligence Unit [16]. This index considers the core issues of affordability, availability and quality of food across 113 countries, using 28 indicators that measure the drivers and underlying factors influencing food security. By analysing conditions at the national level, however, the GFSI does not capture local context or important cultural and political dimensions, but provides a useful approach to understanding the risks to food security.

Furthermore, the National Biodiversity Index (NBI) from the Global Biodiversity Outlook produced by the Secretariat of the Convention of Biological Diversity was also used [17]. This index is based on estimates of country richness and endemism in four terrestrial vertebrate classes and vascular plants. Vertebrates and plants are ranked equally with overall scores normalised ranging from 1 as the maximum for Indonesia, and 0 as the minimum for Greenland.

To create the risk of conflict index, both the GFSI and the NBI were ranked independently. As some countries were not listed on both indexes, there were a total of 107 countries used for this study. Analysis of the frequency distributions of values for both indices showed a normal distribution to ensure compatibility. For the GFSI, 107 was assigned to the country which was the least food secure, whilst 1 was assigned to the country with the highest score. For the NBI, the reverse rank was assigned with the country with the highest biodiversity score being ranked as 107 and with the lowest assigned 1. A combined ranking, the risk of conflict index, was then calculated using the sum of the two ranks for each country. This then showed the countries with the highest risk of conflict between food security and biodiversity as the country with the highest combined rank, having the highest biodiversity relative to the lowest food security.

\subsection{Biodiversity Hotspots}

To examine another proxy for biodiversity, the biodiversity hotspot database [18] was used and overlaid with the Global Food Security Index to examine which hotspots had the highest prevalence of undernourishment. 35 regions have been identified by Conservation International as biodiversity hotspots, meeting the criteria for holding at least 1500 endemic plant species as well as having lost $70 \%$ or more of their original habitat, applying the principles of irreplaceability and vulnerability to guide global conservation planning [19]. Collectively, these regions contained over $50 \%$ of vascular plants 
and $42 \%$ of terrestrial vertebrates as endemics [19], and therefore they are globally significant in terms of biodiversity conservation.

\subsection{Overlap of Biodiversity Indicators with Risk of Agricultural Expansion Index}

On a global scale, climate and soil factors are the main constraints for cultivation for crops [20]. Therefore in the final analysis, a soil dataset from the Conservation Biology Institute [21] was used, showing the overall index of land suitability for cultivation derived as a product of the climate and soil quality limits to cultivation [20]. This was overlaid with a global cropland database [22] to exclude areas which are already cultivated, and the resulting index was used as an indicator of potential threat of agricultural expansion in the future. We analysed croplands here since they are the most intensively managed agricultural lands, with the greatest impact upon native biodiversity. The risk of agricultural expansion index is shown in Figure 1.
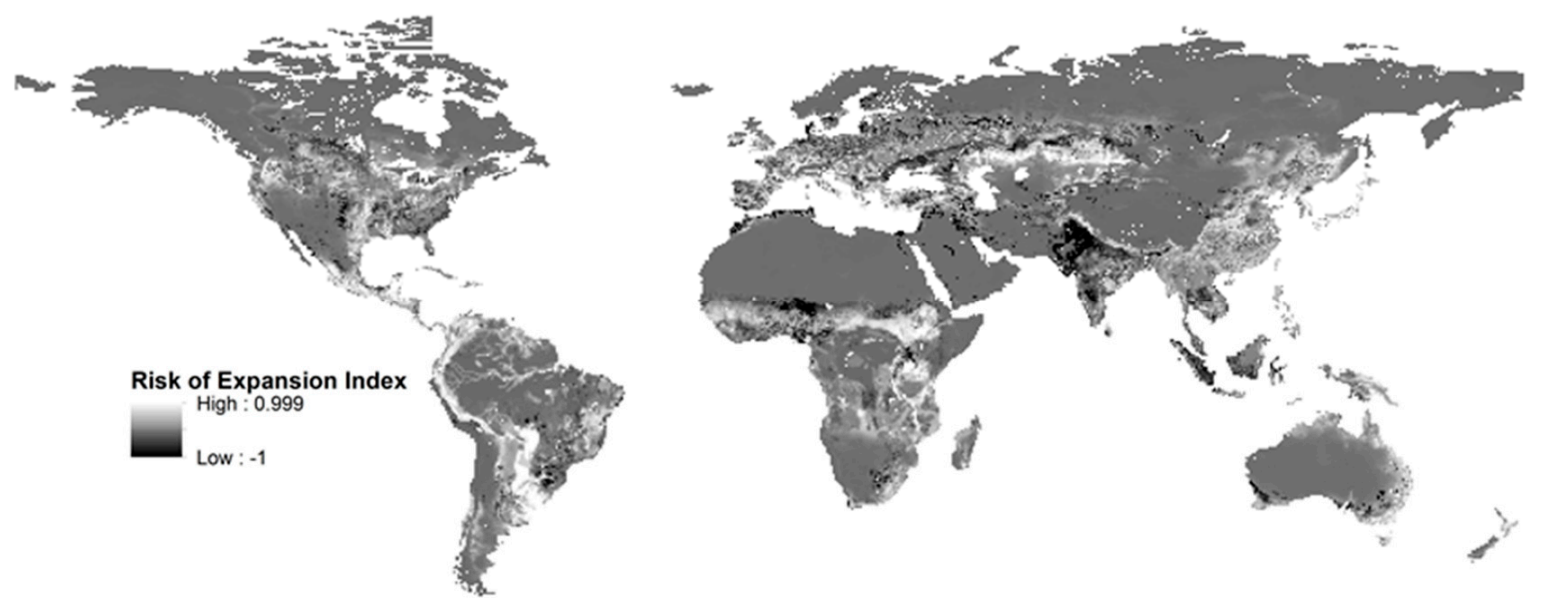

Figure 1. Risk of agricultural expansion index, representing the overlay of agricultural suitability of soil and global croplands database.

The criteria for the biodiversity hotspots database in the previous analysis only takes into account plant species richness. Hence, an analysis using the following species richness datasets as indicators for biodiversity was then conducted:

- $\quad$ species richness for mammals, birds, amphibians [23], and plants [24]

- $\quad$ endemic species richness for mammals, birds, and reptiles using the World Wildlife Fund (WWF) WildFinder database [25]

- globally threatened species richness [26] using the WWF Wildfinder [27] and the International Union for Conservation of Nature (IUCN) Red List [28].

Each biodiversity dataset was overlaid with the risk of agricultural expansion index. The overlap of the top $50 \%$ of both datasets were then examined to show areas of high biodiversity with a high potential threat from future agricultural expansion.

\section{Results}

\subsection{Risk of Conflict Index}

The country with the highest rank i.e. that showing the greatest risk of conflict, was Madagascar followed by Burundi and Haiti (Table 1). 
Table 1. Top 10 countries with highest combined rank (shown in red on Figure 2).

\begin{tabular}{lc}
\hline Country & Combined Rank \\
\hline Madagascar & 195 \\
Burundi & 193 \\
Haiti & 186 \\
Sierra Leone & 182 \\
Congo (Democratic Republic of the) & 176 \\
Togo & 176 \\
Indonesia & 173 \\
Rwanda & 173 \\
Tanzania & 171 \\
Cameroon & 167 \\
\hline
\end{tabular}

The majority of countries with the highest rank, where low food security and high biodiversity simultaneously occur, are located in the tropics (Figure 2). These countries are most at risk of biodiversity being exploited to meet nutritional needs, as there are few alternatives. The country with the lowest combined rank was Ireland, followed by Canada and Sweden, as shown in Table 2. These countries are predominately in temperate regions and represent the lowest risk of conflict between biodiversity and food security, as biodiversity tends to be lower whilst food security is higher.

Table 2. Bottom 10 countries with lowest combined rank (shown in green on Figure 2).

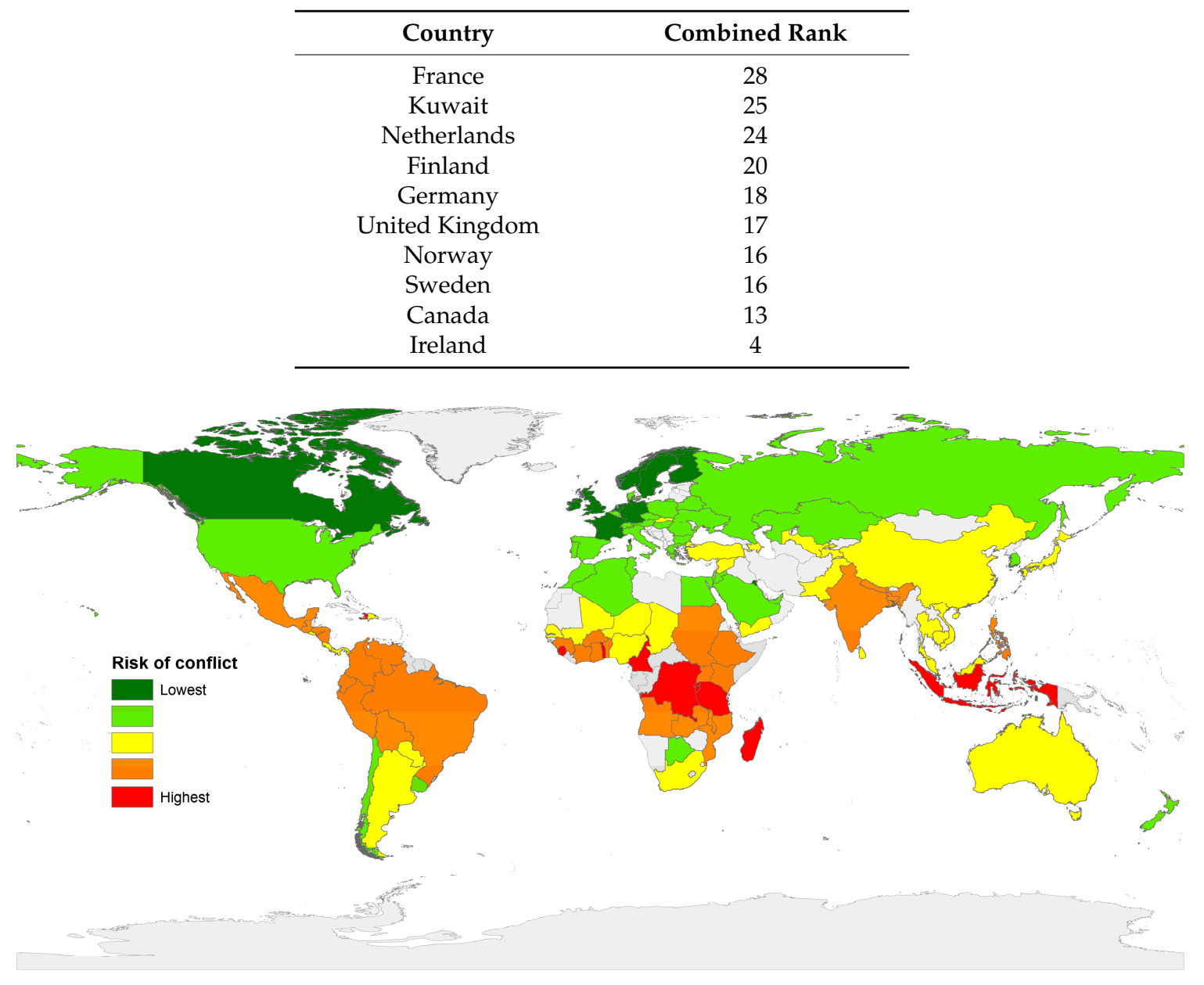

Figure 2. Index of conflict risk between food security and biodiversity. 


\subsection{Biodiversity Hotspots}

The Global Food Security Index was overlaid with biodiversity hotspots as defined by Conservation International in 2011 to indicate regions of global biological significance most affected by high occurrence of hunger (Figure 3).

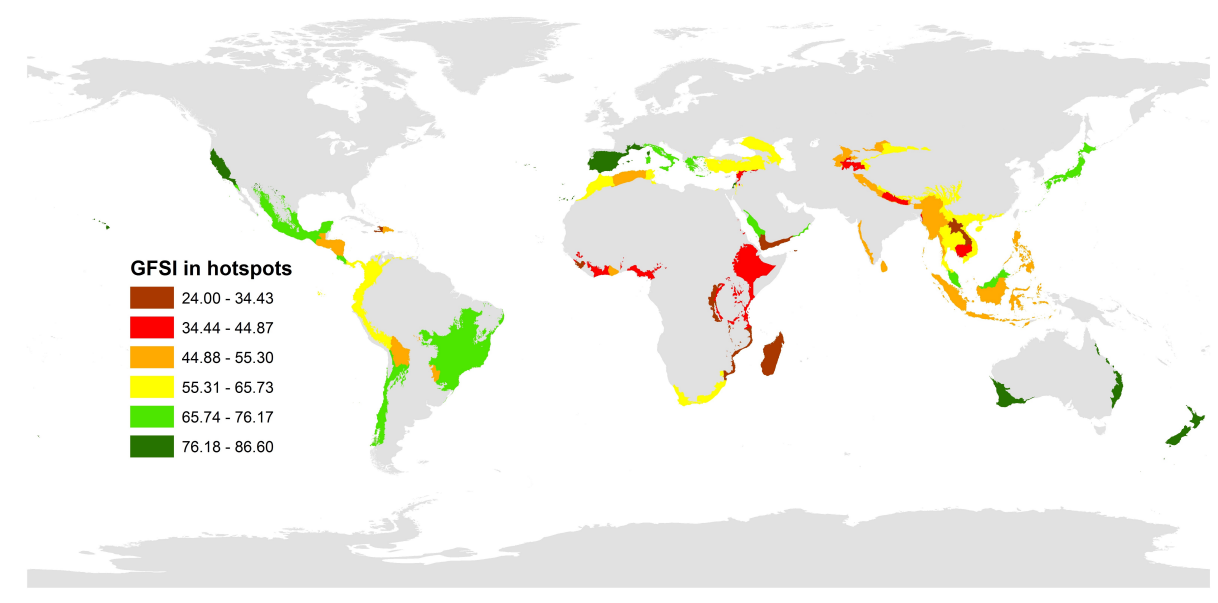

Figure 3. Overlay of biodiversity hotspots and Global Food Security Index (GFSI).

This shows Burundi being the most under pressure, with high biodiversity along the Albertine rift, the Western branch of the East African Rift yet having the highest food insecurity out of all 107 countries (Figure 3, Appendix A). Burundi is followed by Sierra Leone, Haiti, Mozambique, and Eastern Congo, again along the Albertine Rift.

\subsection{Overlap of Biodiversity Indicators with Risk of Agricultural Expansion Index}

Figure 4 shows the top 50\% of the index and species rich areas, as well as the overlap between the two. The majority of the overlap can be seen throughout Central America e.g. Mexico and South America, especially along the Andes mountain range and scattered in areas across Brazil, such as the Amazon basin and the Cerrado. Plant species richness also shows high overlap in South East Asia, in particular China, Indonesia and Papua New Guinea. South Africa also displays some overlap as well as areas in East Africa for mammal and bird species richness.

a)

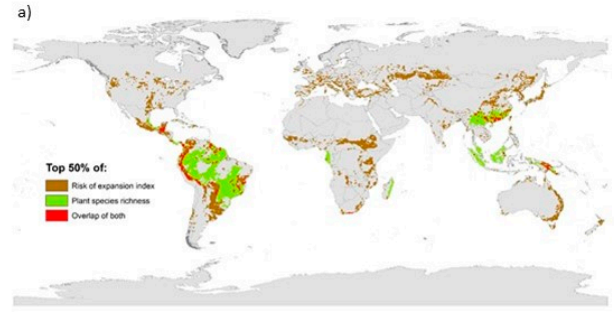

c)

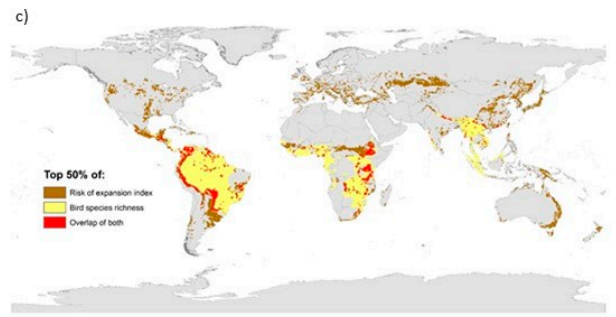

b)
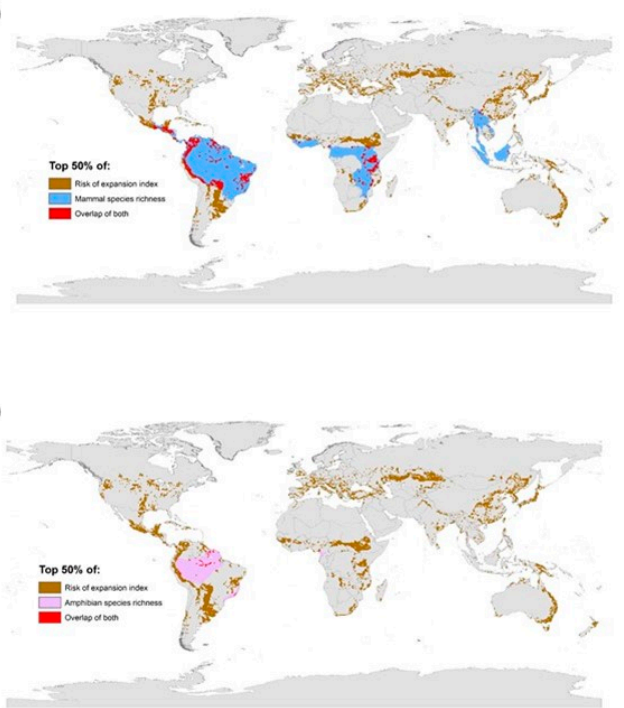

Figure 4. Panel of species richness for (a) plants (b) mammals (c) birds and (d) amphibians overlaid with risk of expansion index. 
A similar methodology was followed for the other two datasets. Figure 5 shows the overlay between the risk of expansion index and species richness of threatened animals as defined by the IUCN Red List. The overlap again shows areas which could be put under most pressure from agricultural expansion which are currently uncultivated and also have a high level of threatened species richness. These areas are the hotspots of potential conflict between agriculture and the conservation of threatened species.

The main areas of overlap are in South America along the Andes mountain range and in South East China. There are also a few areas of overlap in the Cerrado (Brazil), and in other parts of South East Asia, including Indonesia. The island of Borneo is particularly noteworthy for containing high levels of threatened species richness throughout the island, with Malaysia also exhibiting high levels throughout the country.

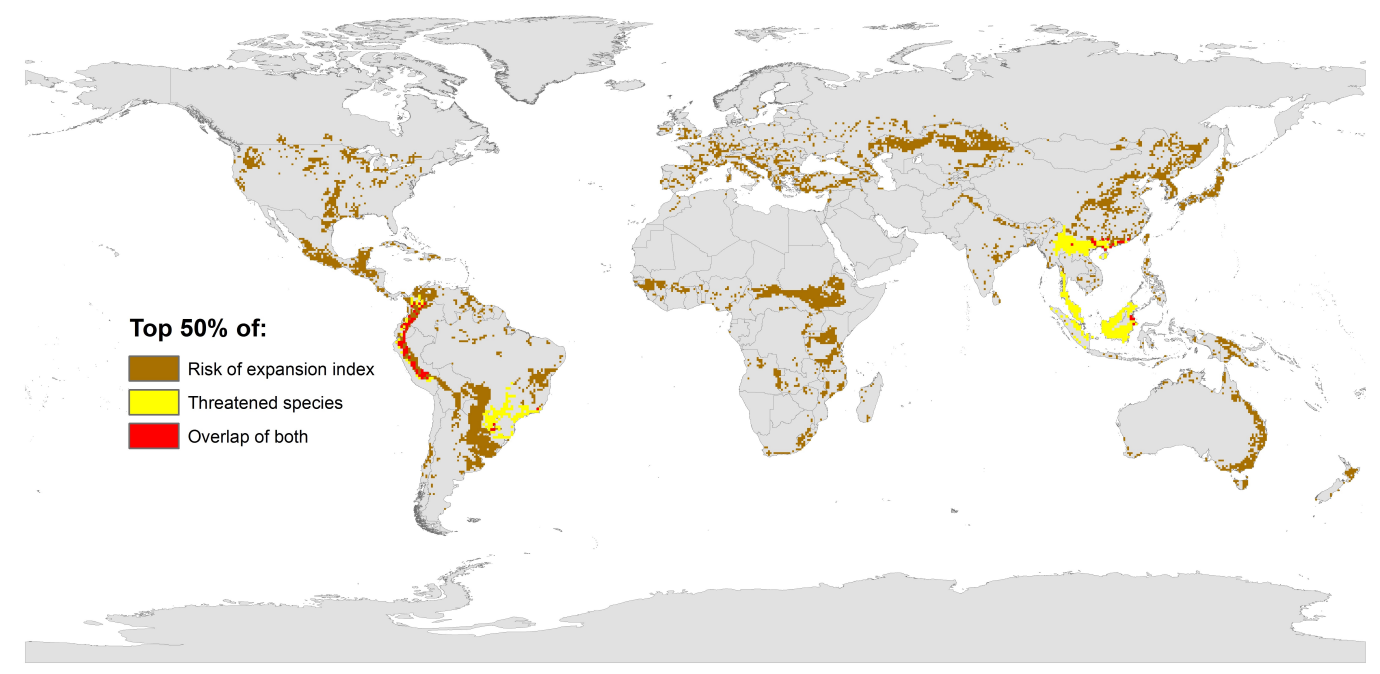

Figure 5. Overlay of threatened species richness and risk of expansion index.

Similarly for endemic species richness, an overlay with the risk of expansion index was conducted as shown in Figure 6. This shows significantly less overlap, with the only major hotspots shown in Peru along the Andes mountain range, Costa Rica, and the Western branch of the Great Rift Valley, also known as the Albertine rift. For endemic species, Madagascar and the southernmost tip of Western India are noteworthy. However, the Solomon Islands contain particularly high biodiversity, with the highest endemic species richness.

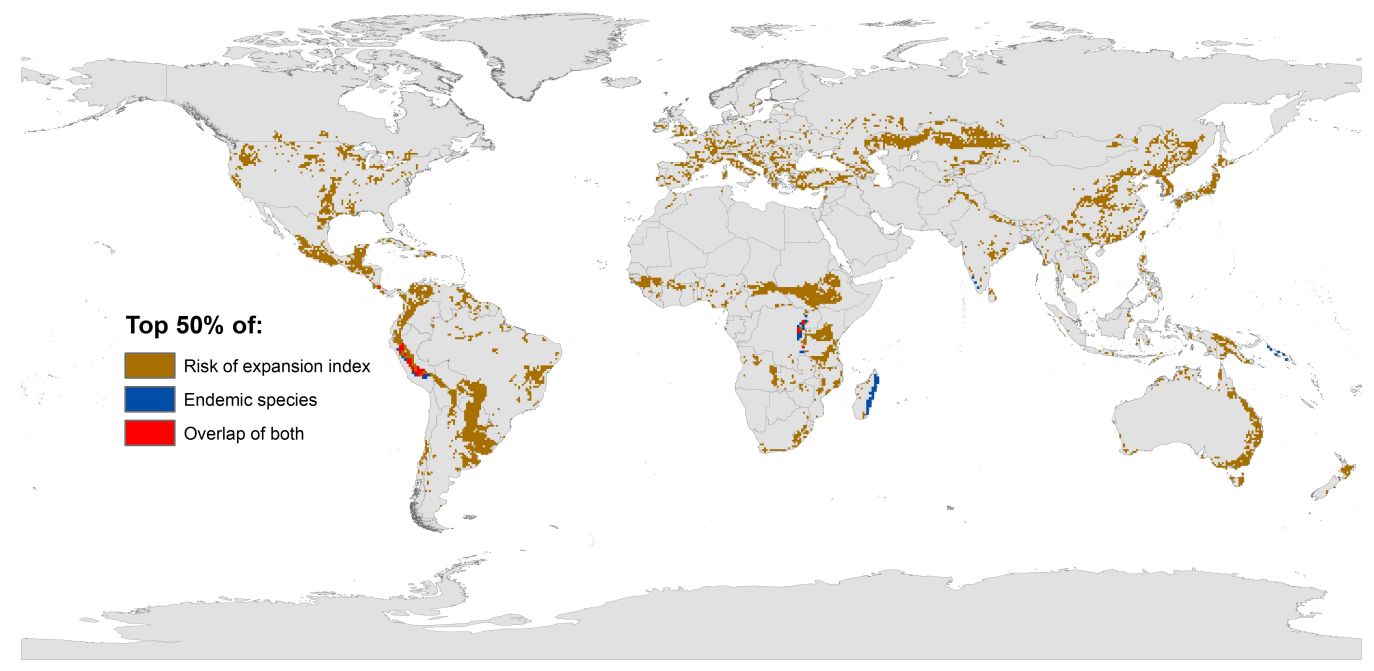

Figure 6. Overlay of endemic species richness and risk of expansion index. 


\section{Discussion}

Madagascar is the country with the highest risk of conflict index (Figure 2). This is because Madagascar had very high biodiversity, with an NBI score of 0.813 (Appendix A), yet low food security and a GFSI score of 31.6. The combined rank reflects these extremes, as Madagascar has the highest risk of conflict score of 195 (Table 1). This is further demonstrated in Figure 3, which shows that the entire country is classified as a biodiversity hotspot, as well as being in the lowest category of the Global Food Security Index (Figure 3).

Madagascar is one of the most important biodiversity hotspots based on richness and endemism of plant species, as well as having ongoing loss of original primary vegetation [29,30]. It stands out from other hotspots because of its endemism at higher taxonomic levels, e.g. genera and families amongst plants and vertebrates, which occurs because its flora and fauna have evolved for long periods largely in isolation [29]. Its biodiversity is demonstrated further in the number of new species discovered recently, with 46 new species identified in the 1990s and 51 new species discovered since 2000 [31]. However, many of these species are highly threatened, which makes Madagascar a global conservation priority [23].

Furthermore, it is characterised by a high level of human dependence on ecosystems [32,33]. Ecosystems are intrinsically important for its economy as a major driver of tourism, as well as for human wellbeing and Malagasy culture [33]. Madagascar has very high levels of poverty, with many people directly depending on natural resources for food, water, and materials [33]. Natural resources also have important cultural and traditional significance to the people; however, despite conservation efforts, habitat loss has continued and has been driven by poverty and food insecurity [32,33]. This habitat loss has intensified with the onset of a political crisis in 2009, since when there have been widespread increases of illegal activities within Madagascar's national parks [34]. Hence the results confirming that Madagascar has a high risk of conflict between food security and biodiversity, is consistent with other studies.

According to the Global Food Security Index 2015 overview, Madagascar (71.8\%) and Rwanda $(71.7 \%)$ had the highest percentages of household expenditure devoted to food consumption [35]. The higher the share of household expenditure on food, the harder it is to cope with price increases and shocks, which demonstrates particularly low food security in both countries [35]. Rwanda, along with Burundi, are also part of the Eastern Afromontane biodiversity hotspot, which harbours tremendously high endemic diversity [23].Burundi and Rwanda are also in the top 10 countries with the highest combined rank (Table 1), and are both in the lowest categories in the Global Food Security Index (Figure 3). They are located along the Albertine Rift area of the hotspot, which encompasses much of the western Rift valley from southern Tanzania to the Rwenzori Mountains, bordering Uganda and the Democratic Republic of the Congo [36]. The Albertine rift is one of the most important regions for conservation in Africa, as it is the most species rich region for vertebrates on the African continent, containing species such as the mountain gorilla [36]. However, it also has a heavy human population pressure with decreasing connectivity between conservation sites [36]. This region is one of the few areas where high endemic species richness overlaps with high risk of agricultural expansion (Figure 6). Furthermore, Hannah et al. [37] classifies the region as a global priority area for funding to support adaptation, to protect agriculture and preserve biodiversity in the face of climate change.

Burundi is of particular concern as it is the country with the lowest GFSI score of 24 (See Appendix A) and is second only to Madagascar in the risk of conflict index (Table 1). Furthermore, in a socio-economic analysis, Burundi was one of the 'hottest hotspots', meaning that it is one of the most biologically important areas most affected by poverty issues [4]. It has also been ranked second globally in a national biodiversity risk assessment to quantify conservation performances and identify countries of critical conservation concern [38]. It is identified as having an exceptionally high biodiversity risk, due to a combination of high pressure on biodiversity, low conservation capacity or investment, lack of economic resources and few 'safe' biological resources [38]. Similarly, Sierra Leone 
is also listed as having a high biodiversity risk, ranked third after Burundi at second [38], and is listed as fourth most at risk in this study (Table 1).

Haiti is the exception, as it is the only country not in Africa in the top five, with Indonesia being the only other country outside of Africa to be in the top ten (Table 1). According to the Global Food Security Index overview, Haiti's score placed it in the bottom tier of the region for every single indicator in the index besides agricultural import tariffs and volatility of agricultural production, which are negatively correlated with food security [35]. Furthermore, the Caribbean Islands are also highlighted as a global priority, with Haiti showing an intersecting agricultural and habitat suitability loss [37].

Hannah et al. [37] also shows several other areas as global priorities which overlap with areas identified in this study, including Madagascar, Central America, and the Andes. Another recent global study also shows similar hotspots, with the 'hottest hotspots' of potential future conflict between biodiversity and agriculture being found in Central America and the Caribbean, south-western Brazil, in West and East Africa, including Madagascar, several parts of tropical Asia and the tropical Andes [39]. The Peruvian Andes were the only region highlighted as an area of overlap in all the maps in the final part of the analysis (Figures 4-6). Previous biodiversity evaluations have designated Peru as a 'megadiverse' country because of the great number of species found within its borders [40]. Within Peru there is incredibly high ecological diversity, with numerous known endemic species of mammals, reptiles, amphibians, flowering plants, and ferns [41]. Hence it is unsurprising that Peru is shown to harbour high biodiversity. However, this area also has a very high risk of agricultural expansion, as it is suitable for agriculture yet currently uncultivated (Figure 1). Since there is no threshold available in the literature, high risk was set as the top $50 \%$ of the scale and likewise for high biodiversity This percentile is arbitrary, yet other percentiles were examined e.g., the top $25 \%$ and found to either show little overlap or similar results to those shown. Other percentiles could be explored in the future, but the $50 \%$ used here demonstrates the utility of the method for identifying hotspots for further examination.

The original data for suitability of soil for agriculture shows that there is a large reserve of cultivable croplands, mainly in tropical South America and Africa [21]. However, this land is often located under valuable forests [21] and as shown in this analysis, overlaps with areas of high biodiversity. These areas also have significant areas that are uncultivated as shown in the risk of expansion index, with Peru, the Albertine rift and South East China showing the highest levels of overlap (Figures 4-6). This is important, as although the majority of future food demand is predicted by the Food and Agricultural Organisation (FAO)to be met through intensification, 20-30\% is forecast to be accounted for by agricultural expansion [14]. There is a subsequent potential biodiversity impact of clearing land not yet used for agriculture but is suitable for agricultural use. Therefore, the areas shown are regarded as at high risk of conflict between food security and biodiversity conservation. Although this is a very broad analysis, it identifies key areas where land is highly suitable for agriculture and largely uncultivated, yet harbours significant biodiversity. This is important for selecting areas for further analysis on smaller scales, exploring in finer detail the interactions between biodiversity and agriculture.

The majority of regions identified as global priorities in this study are located in the tropics, as these areas harbour greater biological diversity [41], yet $55 \%$ of new agricultural land in the tropics has come from conversion of forests [42]. As these countries tend to be poorer, less developed countries, food insecurity can be a driver of this land use change. They also have a narrower scientific base [38], so in order to prevent further biodiversity loss, research is needed on regional scales in the countries identified to prioritise specific areas important for local biodiversity with a high prevalence of food insecurity. The regions identified as global hotspots can allow national conservation agencies to address potential risks within a nation [38]; however specific solutions are likely to be different within each national context. These could range from developing biodiversity friendly farming projects [43], to introducing Payments for Ecosystem Services [44], both of which have seen recent success. 
It is clear that increasing human demand for biologically productive land limits our ability to preserve biodiversity [45]. Habitat conversion reduces local biodiversity [46], and globally it is the dominant driver of biodiversity loss [39]. Therefore, it is largely assumed in this analysis that agricultural land use results in negative consequences for biodiversity. However, it is also important to note that for many small scale farming landscapes, using techniques such as agroforestry and integrated pest management techniques, agricultural land can in fact harbour large amounts of biodiversity [43]. Yet even within wildlife friendly farming systems which support high species richness, a large proportion of wild species cannot survive, even in the most benign agricultural landscapes, and hence protection of wild lands is essential [47].

A main mechanism for reducing risks of conflict between biodiversity conservation and food security is through enhancing self-sufficiency and supporting small scale farming rather than industrialised agriculture [2]. It is well established that small, diversified farms rather than large monocultures show greater productivity per area, yet low input agriculture relies heavily on biodiversity and associated ecosystem services [3]. One study has shown that loss of species richness exceeding $20 \%$ is likely to substantially impair the contribution of biodiversity to ecosystem function and services, and thus human wellbeing [46]. Hence local solutions to ensure that methods of increasing production also preserve functional biodiversity, are essential for reducing risks facing smallholders [3].

Supporting more efficient, profitable, and sustainable production of smallholders could also secure better access to food for the rural poor [3]. Poverty is the main cause of food inaccessibility [2], therefore increasing food production where the hungry live is an important priority for reducing the risk of conflict between these two aims [3]. Co-operation with local policy makers is needed to ensure measures are put in place to increase accessibility which could range from improving public transport to encouraging re-ruralisation and urban agriculture [2]. As the poor often rely heavily on biodiversity and associated ecosystem services, improving accessibility to food can also avoid the potential 'vicious cycle' between poverty and biodiversity loss, where ecosystem degradation and species loss negatively affects local livelihoods, leading to further degradation [4].

Population pressure also contributes to increased pressure on ecosystems, especially in areas of high biodiversity with high natural resource extraction [4]. However, although population is taken into consideration in the Global Food Security Index, it is not explicitly considered in this analysis. Biodiversity threats in heavily populated countries, for example, India and China may therefore be overlooked in this analysis. Population density is a key factor in threats to biodiversity; however on a national scale it depends on the ecological nature of a country, as well as the number of species threatened by extinction [48]. Population growth can also have detrimental effects on biodiversity due to increasing demand for land, for urban expansion, food and energy [49], with land conversion resulting in habitat loss and fragmentation [46]. A more in-depth analysis taking population into account is therefore recommended to examine how this factor changes the results, and which countries would be at higher risk.

Another limitation is that this study focuses on on-site factors; however there are various off-site factors which could also contribute to increasing the risk of conflict between biodiversity and food security. During the past few decades, agricultural trade has increased dramatically, which has led to the globalisation of food products and many countries relying on imports, as opposed to being self-sufficient [50]. This can also impact biodiversity where for example, in Latin America, increasing global food demand has resulted in accelerated deforestation in areas of high potential [51]. This is highlighted in the final analysis, as Latin America shows the greatest area that is potentially threatened by agricultural expansion into areas of high biodiversity (Figures 4-6). Globalisation can bring other risks to both food security and biodiversity such as the introduction of invasive species [2], yet it also has the potential to relieve pressure on marginal ecosystems, as regional specializing in the most locally appropriate land uses can increase global efficiency of land use [52]. There are, however, multiple other trade-offs in the globalised food system on various scales which would need examining in finer 
detail [52]. This would be a key recommendation for further work, as failure to address them could result in increased food insecurity, ecological degradation, and loss of livelihoods [52].

Furthermore, as only single indicators of biodiversity and food security are considered in the first part of the analysis, many sub-national, regional, and local trends have not been considered. The analysis focuses on a global scale identification of hotspots of potential risk of conflict between food security and biodiversity, and so is limited with respect to smaller scale patterns. This is also true for the second analysis showing the overlap of food security indicators with biodiversity hotspots on a global scale. Although this is valuable for demonstrating important ecoregions for biodiversity which are also faced with poverty [4], it also leaves room for further work to be done at a finer resolution. Therefore the importance of this analysis is the usefulness of results for targeting further research.

\section{Conclusions}

This hotspot analysis determines areas of potential conflict between food security and biodiversity conservation. In favour of conducting a global analysis, some aspects including population pressure, off site factors, and regional indicators could not be considered. However, the results provide the basis for detecting priority areas within which further research on finer scales can be conducted, for example in Madagascar and the Peruvian Andes. This is greatly beneficial for directing future work exploring these interactions in greater detail and incorporating the limitations described in this study.

The regions identified coincide with numerous other studies and are mainly located in the tropics, which harbours significant biodiversity, as well as food insecurity being prevalent in many countries. Innovative methods to address these two challenges simultaneously will need well-informed regional and targeted solutions $[3,48]$. Restricting human requirements for land globally will be important for limiting the biodiversity impacts of increasing food production [48], as well as being open to alternative methods of production and new approaches to food choice and diet [2]. High resolution spatial data on biodiversity and land use change will also be required to assist with decision making, allocate funding, and to develop a better understanding of the synergies and trade-offs between biodiversity conservation and food security. However, it is of utmost importance that they are not viewed independently, and there is an increasing need for recognising the strong interdependencies of these two issues.

Acknowledgments: This work contributes to the Belmont Forum/FACCE-JPI DEVIL project (grant number NE/M021327/1), and AM is supported by a BBSRC EastBio Studentship (http://www.eastscotbiodtp.ac.uk/). The Conservation Biology Institute are acknowledged for provision of data as well as BirdLife International, IUCN, NatureServe, and USGS for their contribution of the species range map data used in producing data available from the Biodiversity Mapping website (http:// biodiversitymapping.org).

Author Contributions: A.M. led analysis and writing with contributions from P.S., T.D. and M.K. contributed with technical knowledge of ArcGIS and all authors (A.M., P.S., T.D. and M.K.) contributed to the drafting and revision of the article and have given final approval of the version to be published.

Conflicts of Interest: The authors declare no conflict of interest.

Appendix A. Risk of conflict index showing combined rank and individual index ranks

\begin{tabular}{cccccc}
\hline Country & GFSI & Rank & NBI & Rank & Combined rank \\
\hline Algeria & 54.3 & 61 & 0.308 & 8 & 69 \\
Angola & 33.7 & 96 & 0.641 & 70 & 166 \\
Argentina & 68.3 & 33 & 0.615 & 63 & 96 \\
Australia & 82.6 & 3 & 0.853 & 102 & 105 \\
Austria & 79.3 & 15 & 0.469 & 35 & 50 \\
Azerbaijan & 57.1 & 52 & 0.534 & 49 & 101 \\
Bangladesh & 36.8 & 90 & 0.538 & 51 & 141 \\
Belarus & 63.1 & 42 & 0.368 & 14 & 56 \\
Belgium & 77.4 & 19 & 0.445 & 29 & 48 \\
\hline
\end{tabular}




\begin{tabular}{|c|c|c|c|c|c|}
\hline Country & GFSI & Rank & NBI & Rank & Combined rank \\
\hline Benin & 40.2 & 83 & 0.618 & 65 & 148 \\
\hline Bolivia & 51.6 & 65 & 0.724 & 90 & 155 \\
\hline Botswana & 57.8 & 49 & 0.461 & 33 & 82 \\
\hline Brazil & 67.6 & 37 & 0.877 & 104 & 141 \\
\hline Bulgaria & 60.6 & 46 & 0.493 & 39 & 85 \\
\hline Burkina Faso & 31 & 100 & 0.526 & 48 & 148 \\
\hline Burundi & 24 & 107 & 0.683 & 86 & 193 \\
\hline Cambodia & 39.8 & 84 & 0.568 & 55 & 139 \\
\hline Cameroon & 41.6 & 80 & 0.689 & 87 & 167 \\
\hline Canada & 81.9 & 7 & 0.299 & 6 & 13 \\
\hline Chad & 28.6 & 105 & 0.364 & 11 & 116 \\
\hline Chile & 74.4 & 22 & 0.57 & 56 & 78 \\
\hline China & 65.5 & 38 & 0.839 & 99 & 137 \\
\hline Colombia & 61 & 45 & 0.935 & 106 & 151 \\
\hline Congo (Dem. Rep.) & 30.5 & 101 & 0.651 & 75 & 176 \\
\hline Costa Rica & 68.3 & 34 & 0.82 & 98 & 132 \\
\hline Cote d'Ivoire & 42.3 & 79 & 0.632 & 68 & 147 \\
\hline Czech Republic & 73.9 & 23 & 0.498 & 42 & 65 \\
\hline Denmark & 80 & 13 & 0.403 & 18 & 31 \\
\hline Dominican Republic & 55.1 & 59 & 0.661 & 80 & 139 \\
\hline Ecuador & 57.5 & 51 & 0.873 & 103 & 154 \\
\hline Egypt & 57.1 & 53 & 0.326 & 10 & 63 \\
\hline El Salvador & 53.3 & 64 & 0.616 & 64 & 128 \\
\hline Ethiopia & 34.7 & 93 & 0.593 & 59 & 152 \\
\hline Finland & 78.9 & 16 & 0.29 & 4 & 20 \\
\hline France & 82.5 & 5 & 0.423 & 23 & 28 \\
\hline Germany & 82.5 & 6 & 0.365 & 12 & 18 \\
\hline Ghana & 47.8 & 73 & 0.646 & 74 & 147 \\
\hline Greece & 71.5 & 28 & 0.55 & 54 & 82 \\
\hline Guatemala & 49.6 & 68 & 0.744 & 93 & 161 \\
\hline Guinea & 35 & 92 & 0.603 & 61 & 153 \\
\hline Haiti & 29.4 & 102 & 0.68 & 84 & 186 \\
\hline Honduras & 48.2 & 72 & 0.653 & 77 & 149 \\
\hline Hungary & 69.3 & 30 & 0.441 & 28 & 58 \\
\hline India & 49.4 & 70 & 0.732 & 92 & 162 \\
\hline Indonesia & 50.6 & 66 & 1 & 107 & 173 \\
\hline Ireland & 84.3 & 2 & 0.279 & 2 & 4 \\
\hline Israel & 78.9 & 17 & 0.601 & 60 & 77 \\
\hline Italy & 75.9 & 20 & 0.512 & 44 & 64 \\
\hline Japan & 75.9 & 21 & 0.638 & 69 & 90 \\
\hline Jordan & 56.9 & 55 & 0.468 & 34 & 89 \\
\hline Kazakhstan & 53.7 & 63 & 0.435 & 26 & 89 \\
\hline Kenya & 42.7 & 78 & 0.643 & 72 & 150 \\
\hline Kuwait & 73.5 & 24 & 0.224 & 1 & 25 \\
\hline Madagascar & 31.6 & 98 & 0.813 & 97 & 195 \\
\hline Malawi & 31.4 & 99 & 0.627 & 66 & 165 \\
\hline Malaysia & 69 & 31 & 0.809 & 96 & 127 \\
\hline Mali & 39.3 & 86 & 0.381 & 15 & 101 \\
\hline Mexico & 68.1 & 35 & 0.928 & 105 & 140 \\
\hline Morocco & 55.5 & 57 & 0.459 & 32 & 89 \\
\hline Mozambique & 29.4 & 103 & 0.522 & 47 & 150 \\
\hline Myanmar & 46.5 & 75 & 0.628 & 67 & 142 \\
\hline
\end{tabular}




\begin{tabular}{|c|c|c|c|c|c|}
\hline Country & GFSI & Rank & NBI & Rank & Combined rank \\
\hline Nepal & 42.9 & 77 & 0.642 & 71 & 148 \\
\hline Netherlands & 82.6 & 4 & 0.412 & 20 & 24 \\
\hline New Zealand & 81.1 & 10 & 0.52 & 46 & 56 \\
\hline Nicaragua & 49.4 & 71 & 0.643 & 73 & 144 \\
\hline Niger & 29 & 104 & 0.412 & 21 & 125 \\
\hline Nigeria & 39.4 & 85 & 0.548 & 53 & 138 \\
\hline Norway & 81 & 11 & 0.297 & 5 & 16 \\
\hline Pakistan & 47.8 & 74 & 0.495 & 40 & 114 \\
\hline Panama & 64.4 & 40 & 0.793 & 95 & 135 \\
\hline Paraguay & 54.2 & 62 & 0.613 & 62 & 124 \\
\hline Peru & 57.7 & 50 & 0.843 & 100 & 150 \\
\hline Philippines & 49.5 & 69 & 0.786 & 94 & 163 \\
\hline Poland & 72.4 & 26 & 0.367 & 13 & 39 \\
\hline Portugal & 80 & 14 & 0.511 & 43 & 57 \\
\hline Romania & 65.5 & 39 & 0.424 & 25 & 64 \\
\hline Russia & 62.3 & 44 & 0.447 & 30 & 74 \\
\hline Rwanda & 40.7 & 82 & 0.726 & 91 & 173 \\
\hline Saudi Arabia & 71.1 & 29 & 0.281 & 3 & 32 \\
\hline Senegal & 41 & 81 & 0.512 & 45 & 126 \\
\hline Sierra Leone & 26.1 & 106 & 0.652 & 76 & 182 \\
\hline Slovakia & 67.7 & 36 & 0.589 & 58 & 94 \\
\hline South Africa & 62.9 & 43 & 0.714 & 89 & 132 \\
\hline South Korea & 73.3 & 25 & 0.423 & 24 & 49 \\
\hline Spain & 77.7 & 18 & 0.486 & 37 & 55 \\
\hline Sri Lanka & 54.8 & 60 & 0.656 & 79 & 139 \\
\hline Sudan & 34.7 & 94 & 0.539 & 52 & 146 \\
\hline Sweden & 81.3 & 9 & 0.304 & 7 & 16 \\
\hline Switzerland & 80.9 & 12 & 0.497 & 41 & 53 \\
\hline Syria & 36.3 & 91 & 0.469 & 36 & 127 \\
\hline Tajikistan & 38.6 & 87 & 0.456 & 31 & 118 \\
\hline Tanzania & 36.9 & 89 & 0.674 & 82 & 171 \\
\hline Thailand & 59.5 & 47 & 0.67 & 81 & 128 \\
\hline Togo & 37.9 & 88 & 0.693 & 88 & 176 \\
\hline Tunisia & 57.9 & 48 & 0.408 & 19 & 67 \\
\hline Turkey & 63.6 & 41 & 0.572 & 57 & 98 \\
\hline Uganda & 44.2 & 76 & 0.655 & 78 & 154 \\
\hline Ukraine & 55.2 & 58 & 0.415 & 22 & 80 \\
\hline United Arab Emirates & 71.8 & 27 & 0.392 & 17 & 44 \\
\hline United Kingdom & 81.9 & 8 & 0.32 & 9 & 17 \\
\hline United States & 86.6 & 1 & 0.677 & 83 & 84 \\
\hline Uruguay & 68.4 & 32 & 0.487 & 38 & 70 \\
\hline Uzbekistan & 49.8 & 67 & 0.436 & 27 & 94 \\
\hline Venezuela & 56.9 & 56 & 0.85 & 101 & 157 \\
\hline Vietnam & 57.1 & 54 & 0.682 & 85 & 139 \\
\hline Yemen & 34 & 95 & 0.387 & 16 & 111 \\
\hline Zambia & 33.3 & 97 & 0.537 & 50 & 147 \\
\hline
\end{tabular}




\section{References}

1. Glamann, J.; Hanspach, J.; Abson, D.J.; Collier, N.; Fischer, J. The intersection of food security and biodiversity conservation: A review. Reg. Environ. Chang. 2017, 17, 1303-1313. [CrossRef]

2. Chappell, M.J.; LaValle, L.A. Food security and biodiversity: Can we have both? An agroecological analysis. Agric. Hum. Values 2011, 28, 3-26. [CrossRef]

3. Tscharntke, T.; Clough, Y.; Wanger, T.C.; Jackson, L.; Motzke, I.; Perfecto, I.; Vandermeer, J.; Whitbread, A. Global food security, biodiversity conservation and the future of agricultural intensification. Biol. Conserv. 2012, 151, 53-59. [CrossRef]

4. Fisher, B.; Christopher, T. Poverty and biodiversity: Measuring the overlap of human poverty and the biodiversity hotspots. Ecol. Econ. 2007, 62, 93-101. [CrossRef]

5. Poppy, G.M.; Chiotha, S.; Eigenbrod, F.; Harvey, C.A.; Honzák, M.; Hudson, M.D.; Jarvis, A.J.; Madise, N.J.; Schreckenberg, K.; Villa, F.; et al. Understanding food Security in a perfect storm: An ecosystem services approach. Philos. Trans. R. Soc. 2014, 369. [CrossRef] [PubMed]

6. Snel, M. Poverty-Conservation Mapping Applications. In Proceedings of the IUCN World Conservation Congress, Bangkok, Thailand, 17-25 November 2004; pp. 1-20.

7. FAO. An Introduction to the Basic Concepts of Food Security; Food Security Information for Action, FAO: Rome, Italy, 2008.

8. Foresight, U.K. The Future of Food and Farming; Final Project Report; The Government Office for Science: London, UK, 2011.

9. FAO; IFAD; WFP. Meeting the 2015 International Hunger Targets: Taking Stock of Uneven Progress; The State of Food Insecurity in the World; FAO: Rome, Italy, 2015.

10. Brussaard, L.; Caron, P.; Campbell, B.; Lipper, L.; Mainka, S.; Rabbinge, R.; Babin, D.; Pulleman, M. Reconciling biodiversity conservation and food security: Scientific challenges for a new agriculture. Curr. Opin. Environ. Sustain. 2010, 2, 34-42. [CrossRef]

11. Pinstrup-Andersen, P. Food security: Definition and measurement. Food Secur. 2009, 1, 5-7. [CrossRef]

12. Baillie, J.; Hilton-Taylor, C.; Stuart, S.N. 2004 IUCN Red List of Threatened Species: A Global Species Assessment; IUCN: Gland, Switzerland, 2004.

13. Alexandratos, N.; Bruinsma, J. World Agriculture towards 2030/2050: The 2012 Revision; FAO: ESA Working Paper; No. 12-03; FAO: Rome, Italy, 2012; p. 4.

14. Foley, J.A.; DeFries, R.; Asner, G.P.; Barford, C.; Bonan, G.; Carpenter, S.R.; Chapin, F.S.; Coe, M.T.; Daily, G.C.; Gibbs, H.K.; et al. Global consequences of land use. Science 2005, 309, 570-574. [CrossRef] [PubMed]

15. Pouzols, F.M.; Toivonen, T.; Di Minin, E.; Kukkala, A.S.; Kullberg, P.; Kuusterä, J.; Lehtomäki, J.; Tenkanen, H.; Verburg, P.H.; Moilanen, A. Global protected area expansion is compromised by projected land-use and parochialism. Nature 2014, 516, 383-386. [CrossRef] [PubMed]

16. The Economist Intelligence Unit. Global Food Security Index 2016; The Economist Intelligence Unit Ltd.: London, UK, 2016; Available online: http:/ / foodsecurityindex.eiu.com/ (accessed on 13 May 2017).

17. Secretariat of the Convention on Biological Diversity. Global Biodiversity Outlook; Convention of Biological Diversity: Montreal, QC, Canada, 2001; Available online: https://www.cbd.int/gbo1/annex.shtml (accessed on 28 August 2016).

18. Mittermeier, R.A.; Robles-Gil, P.; Hoffmann, M.; Pilgrim, J.D.; Brooks, T.B.; Mittermeier, C.G.; Lamoreux, J.L.; Fonseca, G.A.B. Hotspots Revisited: Earths Biologically Richest and Most Endangered Ecoregions; CEMEX: Mexico City, Mexico, 2004; p. 390.

19. Mittermeier, R.A.; Turner, W.R.; Larsen, F.W.; Brooks, T.M.; Gascon, C. Global biodiversity conservation: The critical role of hotspots. In Biodiversity Hotspots; Springer: Berlin/Heidelberg, Germany, 2011; pp. 3-22.

20. Ramankutty, N.; Foley, J.A.; Norman, J.; Mcsweeney, K. The global distribution of cultivable lands: Current patterns and sensitivity to possible climate change. Glob. Ecol. Biogeogr. 2002, 11, 377-392. [CrossRef]

21. Ramankutty, N.; Foley, J.A.; Norman, J.; Mcsweeney, K. Agricultural Suitability of Global Soils. 2001 Data Available from Conservation Biology Institute. Available online: https:/ / databasin.org/datasets/ fdfcc35510ba44ac8c174221f1762e2d (accessed on 29 March 2016).

22. Ramankutty, N.; Evan, A.T.; Monfreda, C.; Foley, J.A. Farming the planet: 1. Geographic distribution of global agricultural lands in the year 2000. Glob. Biogeochem. Cycles 2008, 22, 567-568. [CrossRef] 
23. Jenkins, C.N.; Pimm, S.L.; Joppa, L.N. Global patterns of terrestrial vertebrate diversity and conservation. Proc. Natl. Acad. Sci. USA 2013, 110, E2602-E2610. [CrossRef] [PubMed]

24. Kier, G.; Mutke, J.; Dinerstein, E.; Ricketts, T.H.; Küper, W.; Kreft, H.; Barthlott, W. Global patterns of plant diversity and floristic knowledge. J. Biogeogr. 2005, 32, 1107-1116. [CrossRef]

25. Terrestrial Endemic Species Richness by Ecoregion: World Wildlife Fund (WWF); WildFinder: Database of Species Distributions. Available online: http://www.arcgis.com/home/item.html?id= 814f74a250ec42bf87ab8c80ea811c7f (accessed on 17 February 2016).

26. Hoekstra, J.M.; Molnar, J.L.; Jennings, M.; Revenga, C.; Spalding, M.D.; Boucher, T.M.; Robertson, J.C.; Heibel, T.J.; Ellison, K. The Atlas of Global Conservation: Changes, Challenges, and Opportunities to Make a Difference; Molnar, J.L., Ed.; University of California Press: Berkeley, CA, USA, 2010.

27. World Wildlife Fund (WWF). WildFinder: Database of Species Distributions, ver. Jan-06. 2006. Available online: https: / / www.worldwildlife.org/pages/wildfinder (accessed on 20 March 2016).

28. International Union for Conservation of Nature (IUCN). IUCN Red List of Threatened Species Summary Statistics. Available online: www.redlist.org (accessed on 20 March 2016).

29. Myers, N.; Mittermeier, R.A.; Mittermeier, C.G.; Da Fonseca, G.A.; Kent, J. Biodiversity hotspots for conservation priorities. Nature 2000, 403, 853-858. [CrossRef] [PubMed]

30. Ingram, J.C.; Dawson, T.P. Technical Note: Inter-annual analysis of deforestation hotspots in Madagascar from high temporal resolution satellite observations. Int. J. Remote Sens. 2005, 26, 1447-1461. [CrossRef]

31. Vieites, D.R.; Wollenberg, K.C.; Andreone, F.; Köhler, J.; Glaw, F.; Vences, M. Vast underestimation of Madagascar's biodiversity evidenced by an integrative amphibian inventory. Proc. Natl. Acad. Sci. USA 2009, 106, 8267-8272. [CrossRef] [PubMed]

32. Dawson, T.; Ingram, J.C. Sustainable livelihoods and forest resources in Madagascar: A multi-scale analysis using remote sensing. Environ. Sci. 2008, 5, 129-143. [CrossRef]

33. Neugarten, R.A.; Honzák, M.; Carret, P.; Koenig, K.; Andriamaro, L.; Cano, C.A.; Grantham, H.S.; Hole, D.; Juhn, D.; McKinnon, M.; et al. Rapid assessment of ecosystem service co-benefits of biodiversity priority areas in Madagascar. PLoS ONE 2016, 11, e0168575. [CrossRef] [PubMed]

34. Allnutt, T.F.; Asner, G.P.; Golden, C.D.; Powell, G.V. Mapping recent deforestation and forest disturbance in northeastern Madagascar. Trop. Conserv. Sci. 2013, 6, 1-15. [CrossRef]

35. Alarcon, D.; Grundleger, J.; Joehnk, T.F.; Koch, B.; Lake, J.; Luft, J.; Morgan, J.; Powell, R. Global Food Security Index 2015: An Annual Measure of the State of Global Food Security; A Report from the Economist Intelligence Unit; EIU: London, UK, 2015; pp. 1-44.

36. Plumptre, A.J.; Davenport, T.R.; Behangana, M.; Kityo, R.; Eilu, G.; Ssegawa, P.; Ewango, C.; Meirte, D.; Kahindo, C.; Herremans, M.; et al. The biodiversity of the Albertine Rift. Biol. Conserv. 2007, 134, 178-194. [CrossRef]

37. Hannah, L.; Ikegami, M.; Hole, D.G.; Seo, C.; Butchart, S.H.; Peterson, A.T.; Roehrdanz, P.R. Global climate change adaptation priorities for biodiversity and food security. PLoS ONE 2013, 8, e72590. [CrossRef] [PubMed]

38. Reyers, B.; Jaarsveld, A.S.V.; McGeoch, M.A.; James, A.N. National biodiversity risk assessment: A composite multivariate and index approach. Biodivers. Conserv. 1998, 7, 945-965. [CrossRef]

39. Delzeit, R.; Zabel, F.; Meyer, C.; Václavík, T. Addressing future trade-offs between biodiversity and cropland expansion to improve food security. Reg. Environ. Chang. 2017, 17, 1429-1441. [CrossRef]

40. McNeely, J.; Miller, K.; Reid, W.; Mittermeier, R.; Werner, T. Conserving the World's Biological Diversity; IUCN: Gland, Switzerland; World Bank: Washington, DC, USA, 1990.

41. Rodríguez, L.O.; Young, K.R. Biological diversity of Peru: Determining priority areas for conservation. AMBIO A J. Hum. Environ. 2000, 29, 329-337. [CrossRef]

42. Johnson, J.A.; Runge, C.F.; Senauer, B.; Foley, J.; Polasky, S. Global agriculture and carbon trade-offs. Proc. Natl. Acad. Sci. USA 2014, 111, 12342-12347. [CrossRef] [PubMed]

43. McNeely, J.A.; Scherr, S.J. Ecoagriculture: Strategies to Feed the World and Save Wild Biodiversity; Island Press: Washington, DC, USA, 2003.

44. Pagiola, S. Payments for environmental services in Costa Rica. Ecol. Econ. 2008, 65, 712-724. [CrossRef]

45. Weinzettel, J.; Hertwich, E.G.; Peters, G.P.; Steen-Olsen, K.; Galli, A. Affluence drives the global displacement of land use. Glob. Environ. Chang. 2013, 23, 433-438. [CrossRef] 
46. Newbold, T.; Hudson, L.N.; Hill, S.L.; Contu, S.; Lysenko, I.; Senior, R.A.; Börger, L.; Bennett, D.J.; Choimes, A.; Collen, B.; et al. Global effects of land use on local terrestrial biodiversity. Nature 2015, 520, 45-50. [CrossRef] [PubMed]

47. Phalan, B.; Balmford, A.; Green, R.E.; Scharlemann, J.P. Minimising the harm to biodiversity of producing more food globally. Food Policy 2011, 36, S62-S71. [CrossRef]

48. McKee, J.K.; Sciulli, P.W.; Fooce, C.D.; Waite, T.A. Forecasting global biodiversity threats associated with human population growth. Biol. Conserv. 2004, 115, 161-164. [CrossRef]

49. Smith, P.; Gregory, P.J.; Van Vuuren, D.; Obersteiner, M.; Havlík, P.; Rounsevell, M.; Woods, J.; Stehfest, E.; Bellarby, J. Competition for land. Philos. Trans. R. Soc. Lond. B Biol. Sci. 2010, 365, 2941-2957. [CrossRef] [PubMed]

50. D'Odorico, P.; Carr, J.A.; Laio, F.; Ridolfi, L.; Vandoni, S. Feeding humanity through global food trade. Earth's Future 2014, 2, 458-469. [CrossRef]

51. Lambin, E.F.; Meyfroidt, P. Global land use change, economic globalization, and the looming land scarcity. Proc. Natl. Acad. Sci. USA 2011, 108, 3465-3472. [CrossRef] [PubMed]

52. Ericksen, P.J.; Ingram, J.S.; Liverman, D.M. Food security and global environmental change: Emerging challenges. Environ. Sci. Policy 2009, 12,373-377. [CrossRef]

(c) 2017 by the authors. Licensee MDPI, Basel, Switzerland. This article is an open access article distributed under the terms and conditions of the Creative Commons Attribution (CC BY) license (http://creativecommons.org/licenses/by/4.0/). 